\title{
IMPACT OF SALINE CONDITIONS AND NITROGEN FERTILIZATION ON CITRUS PRODUCTION AND GAS EXCHANGES ${ }^{1}$
}

\author{
JÔNATAS RAULINO MARQUES DE SOUSA ${ }^{2 *}$, HANS RAJ GHEYI ${ }^{3}$, MARCOS ERIC BARBOSA BRITO ${ }^{4}$, DIEGO \\ AZEVEDO XAVIER ${ }^{2}$, GUILHERME DE FREITAS FURTADO ${ }^{2}$
}

\begin{abstract}
In two simultaneous experiments, we evaluated the impact of brackish irrigation water and nitrogen $(\mathrm{N})$ fertilization on the production of citrus (scion-rootstock combinations) and its associated gas exchanges. These experiments were conducted at the Campus of Federal University of Campina Grande, Brazil in a protected environment (shade screens on the sides) using drainage lysimeters. Experiment I used a randomized block design ( 3 replicates), in a $5 \times 3$ factorial arrangement, corresponding to five water salinity levels $\left(0.6,1.2,1.8,2.4\right.$, and $\left.3.0 \mathrm{dS} \mathrm{m}^{-1}\right)$ and three scion-rootstock combinations: RS1- Common Sunki mandarin $($ TSKC) $\times$ Poncirus trifoliata English $($ TRENG) - 256; RS2- Common Rangpur lime (LCRSTC); and RS3 - TSKC $\times($ Rangpur lime $(\mathrm{LCR}) \times P$. trifoliata $(\mathrm{TR}))-059$; with Mimo do Céu orange as the scion variety. Experiment II used a randomized block design ( 3 replicates), in a $3 \times 2$ factorial arrangement, corresponding to the three scion/rootstock combinations and two nitrogen $(\mathrm{N})$ doses (100 and $200 \mathrm{mg} \mathrm{kg}^{-1} \mathrm{of}_{\text {soil }}$. Plants were irrigated with water of $3.0 \mathrm{dS} \mathrm{m}^{-1}$. For both experiments, gas exchanges and mean mass of fruits were evaluated at harvest. Gas exchanges were inhibited in plants under saline stress. Plants grafted with Common Rangpur lime showed greater production potential than did the other genotypes studied, even under brackish water conditions.
\end{abstract}

Keywords: Citrus spp.. Physiology. Saline stress. Mimo-do-Céu orange.

\section{TROCAS GASOSAS E PRODUÇÃO DE CITROS IRRIGADOS COM ÁGUAS SALINAS E ADUBAÇÃO NITROGENADA}

\begin{abstract}
RESUMO - Em dois experimentos simultâneos, avaliou-se o impacto da irrigação com água salinizadas e da adubação nitrogenada $(\mathrm{N})$ sobre a produção de citros (combinações copa/porta-enxerto) e suas trocas gasosas. Estes experimentos foram realizados no Campus da Universidade Federal de Campina Grande, Brasil, em um ambiente protegido (telas de sombrite nas laterais), utilizando lisímetros de drenagem. No Experimento I utilizou-se um delineamento em blocos casualizados ( 3 repetições), em esquema fatorial 5 x 3, correspondendo a cinco níveis de salinidade da água $\left(0,6 ; 1,2 ; 1,8 ; 2,4\right.$ e $\left.3,0 \mathrm{dS} \mathrm{m}^{-1}\right)$ e três combinações de copa/porta-enxertos: RS1 - Sunki comum mandarim (TSKC) x Poncirus trifoliata Inglês (Treng) - 256; RS2 - Comum limão Cravo $($ LCR TC); e RS3 - TSKC $\times($ limão Cravo $($ LCR $) \times P$. trifoliata $($ TR $))-059$; com Mimo do Céu laranja como a variedade copa. No Experimento II utilizou um delineamento em blocos casualizados (3 repetições), em esquema fatorial $3 \times 2$, correspondendo a três combinações de copa/porta-enxerto e duas doses de nitrogênio (N) (100 e $200 \mathrm{mg} \mathrm{kg}^{-1}$ de solo). As plantas foram irrigadas com água de 3,0 $\mathrm{dS} \mathrm{m}^{-1}$. Em ambos os experimentos, as trocas gasosas e a massa média dos frutos foram avaliados na colheita. As trocas gasosas foram inibidas em plantas sob estresse salino. Plantas enxertadas com limoeiro Cravo Comum apresentaram maior potencial de produção quando comparado aos outros genótipos estudados, mesmo em condições de água salina.
\end{abstract}

Palavras-chave: Citrus spp.. Fisiologia. Estresse salino. Laranja 'Mimo-do-Céu’.

\footnotetext{
*Corresponding author

${ }^{1}$ Received for publication in 10/15/2014; accepted in 02/16/2016.

Paper extracted from the Masters' Dissertation of the first author.

${ }^{2}$ Department of Agricultural Engineering, Universidade Federal de Campina Grande, Campina Grande, PB, Brazil; jonatasraulyno@gmail.com, daxengagricola@gmail.com, gfreitasagro@gmail.com.

${ }^{3}$ Nucleus of Weter and Soil Engineering, Universidade Federal de Recôncavo da Bahia, Cruz das Almas, BA, Brazil; hans@pq.cnpq.br.

${ }^{4}$ Department of Agricultural Sciences, Universidade Federal de Campina Grande, Pombal, PB, Brazil; marcoseric@ccta.ufcg.edu.br.
} 


\section{INTRODUCTION}

Brazil is the global leader in the total production of citrus $(18 \mathrm{Mt})$. However, average yield is relatively low in Brazil (24.69 $\mathrm{t} \mathrm{ha}^{-1}$ ) compared to in the United States $\left(31.75 \mathrm{t} \mathrm{ha}^{-1}\right)$, South Africa (35.62 $\left.\mathrm{t} \mathrm{ha}^{-1}\right)$, and Turkey (40.09 $\left.\mathrm{t} \mathrm{ha}^{-1}\right)$ (FAO, 2013). This low yield can be attributed to the little use of fundamental technologies (e.g., irrigation), especially in the northeast region of Brazil, which has the lowest yield in the country $\left(14.79 \mathrm{t} \mathrm{ha}^{-1}\right)$, despite being the country's second largest orange-producing region (2 Mt) (IBGE, 2013).

In order to improve yield in Brazil, irrigation must be expanded, especially in the northeast region, approximately $90 \%$ of which is under semiarid conditions. However, because of the high amount of water needed for irrigation, consideration must be given to sources of low-quality water, such as brackish water. According to Neves et al. (2009), in the Brazilian semiarid region, it is common for farmers to use water with high concentrations of salts (e.g., sodium salts), and this use causes negative effects on the soil and cultivated plants. Therefore, in order for irrigation to be sustainable, alternative strategies must be found for using brackish water.

One possible strategy is to use cultivars/ genotypes that are tolerant to saline conditions and capable of producing economically viable yields (FERNANDES et al., 2011; BRITO et al., 2014b). Citrus crops are sensitive to salinity (SYVERTSEN; SANCHEZ, 2014), and therefore tolerance to salinity needs to be investigated at the scion-rootstock level. Brito et al. (2014a) revealed the importance of the rootstock, in relation to the scion, in order to obtain citrus materials tolerant to salinity, and recommended the Cravo Santa Cruz lemon, the 069 trifoliate hybrid, and Volkamer lemon rootstocks, which are tolerant to electrical conductivity levels of up to $2.4 \mathrm{dS} \mathrm{m}^{-1}$.

Different nitrogen (N) fertilizers can also affect crop growth under saline conditions. Application of nitric $\left(\mathrm{NO}_{3}{ }^{-}\right)$fertilizer above the recommended dose can balance cations and anions, and improve the absorption of nutrients by plants. On the other hand, the application of ammonium $\left(\mathrm{NH}_{4}{ }^{+}\right)$can contribute to a higher absorption of anions and, in salt-affected soils with high amounts of chlorides, $\mathrm{NH}_{4}^{+}$will be absorbed preferentially, causing lower damages to plants. Preliminary results have been observed in experiments with castor bean (SOARES et al., 2013; LIMA et al., 2014) and sunflower (NOBRE et al., 2011; NOBRE et al., 2014).

For citrus, more research is needed on the effect of $\mathrm{N}$ fertilization and saline stress on crop production. In particular, it is necessary to evaluate the physiological nature (e.g., gas exchanges) of the responses, similar to recent studies on citrus plants under water stress (BRITO et al., 2012) and citrus rootstocks under saline stress (SILVA et al., 2014).

This study aimed to evaluate gas exchanges and the mean mass of citrus fruits for scion/rootstock combinations applied with saline water and $\mathrm{N}$ fertilizer.

\section{MATERIAL AND METHODS}

\section{Study area}

Two experiments were conducted simultaneously in a protected environment (screened, without plastic cover) at the Federal University of Campina Grande's Center of Technology and Natural Resources' Academic Unit of Agricultural Engineering in Campina Grande-PB, Brazil $\left(7^{\circ} 15^{\prime}\right.$ $\left.18^{\prime \prime} \mathrm{S} ; 35^{\circ} 52^{\prime} 28^{\prime \prime} \mathrm{W} ; 550 \mathrm{~m}\right)$. According to Köppen's classification, the climate of in the area is As.

\section{Experimental design}

In the first experiment (Experiment I), the treatments were arranged in a randomized block design using a $5 \times 3$ factorial scheme, with five levels of electrical conductivity of water $(\mathrm{ECW})(0.6$, $1.2,1.8,2.4$, and $\left.3.0 \mathrm{dS} \mathrm{m}^{-1}\right)$ and three scionrootstock combinations (Table 1). There were three replicates and one plant was used per plot.

Table 1. Combinations of scion-rootstock included in the experiments.

\begin{tabular}{cl}
\hline Scion & \multicolumn{1}{c}{ Rootstock (RS) } \\
\hline & RS1 - TSKC ('Common Sunki’ mandarin (Citrus sunki (Hayata) hort. ex Tanaka)) \\
"Mimo do Céu” orange & x TRENG (Poncirus Trifoliata 'English’) - 256 \\
& RS2 - LCRC ('Common’ Rangpur lime (Citrus limonia L. Osbeck)) \\
& RS3 - TSKC x (Rangpur lime (LCR) x Poncirus Trifoliata (TR)) - 059. \\
\hline
\end{tabular}

The second experiment (Experiment II) evaluated the impact of $\mathrm{N}$ fertilization on reducing the negative effects of salinity. Thus, additional plants were irrigated with water of $3.0 \mathrm{dS} \mathrm{m}^{-1}$ and subjected to $200 \%$ of the $\mathrm{N}$ fertilization dose proposed by Novais et al. (1991). The obtained data were compared with the results of plants irrigated with water of $3.0 \mathrm{dS} \mathrm{m}^{-1}$ from Experiment $\mathrm{I}$, in which $\mathrm{N}$ fertilization corresponded to $100 \%$ of the recommendation. The data were analyzed in a randomized block design using a $3 \times 2$ factorial scheme, corresponding to the three scion-rootstock combinations (refered in Experiment I) and two $\mathrm{N}$ doses (100 and $200 \mathrm{mg} \mathrm{kg}^{-1}$ of soil). Urea (45\% of 
$\mathrm{N})$ was used as the $\mathrm{N}$ source as it has a high $\mathrm{N}$ concentration and a low cost/benefit ratio (MARCHESAN et al., 2011).

\section{Experimental details}

The experiments were conducted from July 30, 2013 to February 28, 2014 using 2-year-old plants, and encompassed the period between pre-flowering and the first commercial production.

Both experiments used drainage lysimeters (0.70 m height; $0.57 \mathrm{~m}$ diameter; $150 \mathrm{~L}$ capacity), which were distributed in single rows, at a spacing of $1.50 \mathrm{~m}$ between rows and $1 \mathrm{~m}$ between plants. In order to facilitate the drainage of excess irrigation water, the lysimeters were filled with a 0.10 -m layer of crushed stone $(5 \mathrm{~mm})$ and a 0.10 -m layer of sand. The lysimeters were then filled ( $0.40 \mathrm{~m}$ layer), with $200 \mathrm{~kg}$ of Regolithic Neosol (soil without salinity or sodicity problem collected from a $0-0.30 \mathrm{~m}$ soil depth; Table 2), and $38 \mathrm{~kg}$ mixture of soil and humus (corresponding to $4.76 \mathrm{~kg}$ equivalent to $2 \%$ of the total soil mass). In total, $0.60 \mathrm{~m}$ of each lysimeter was filled, which left $0.1 \mathrm{~m}$ at the top for irrigation.

Table 2. Physical and chemical properties of the soil used in the experiments.

\begin{tabular}{ccccccccccc}
\hline \multirow{2}{*}{$\begin{array}{c}\text { Bulk } \\
\text { Density }\end{array}$} & \multirow{2}{*}{ Total Porosity } & \multirow{2}{*}{ Sand } & \multirow{2}{*}{ Silt } & \multirow{2}{*}{ Clay } & \multicolumn{4}{c}{ Exchange complex } & \multirow{2}{*}{$\mathrm{CH}_{\mathrm{sp}}$} & \multirow{2}{*}{$\mathrm{EC}_{\mathrm{se}}$} \\
\hline $\mathrm{kg} \mathrm{dm}^{-3}$ & $\%$ & & $\mathrm{~g} \mathrm{~kg}^{-1}$ & & & $\mathrm{Mg}^{2+}$ & $\mathrm{Na}^{+}$ & $\mathrm{K}^{+}$ & & \\
\hline 1.42 & 49.47 & 734 & 168 & 98 & 1.88 & 3.13 & 1.64 & 0.06 & 4.72 & 0.66 \\
\hline
\end{tabular}

$\mathrm{Ca}^{2+}$ and $\mathrm{Mg}^{2+}$ extracted with $1 \mathrm{M} \mathrm{KCl}$ at $\mathrm{pH} 7.0 ; \mathrm{Na}^{+}$and $\mathrm{K}^{+}$extracted using $1 \mathrm{M} \mathrm{NH}_{4} \mathrm{OAC}$ at $\mathrm{pH} 7.0 ; \mathrm{pH}_{\mathrm{sp}}-\mathrm{pH}$ of the saturated paste; $\mathrm{EC}_{\mathrm{se}}$ - electrical conductivity of the saturation extract.

Based on recommendations of Novais et al. (1991) for experiments in controlled environments, the treatments received a monthly $\mathrm{N}, \mathrm{P}$, and $\mathrm{K}$ top-dressing fertilization. Additionally, the commercial foliar fertilizer "Albatroz" (N-7\%;
$\mathrm{P}_{2} \mathrm{O}_{5}-17 \% ; \quad \mathrm{K}_{2} \mathrm{O}-35 \% ; \quad \mathrm{MgO}-3 \% ; \quad \mathrm{Ca}-0.10 \%$; B- $0.02 \%$; $\mathrm{Cu}-0.02 \%$ ) was employed at a dose of $1 \mathrm{~g}$ $\mathrm{L}^{-1}$. The supplemental $\mathrm{N}$ fertilization in Experiment II was applied 15 days after the usual fertilization with $100 \mathrm{mg} \mathrm{kg}^{-1}$ of soil (Table 3 ).

Table 3. Fertilization management during the experiment.

\begin{tabular}{cccc}
\hline & Nitrogen $(\mathrm{N})$ & Phosphorus $(\mathrm{P})$ & Potassium $(\mathrm{K})$ \\
\cline { 2 - 4 } Recommendation $\left(\mathrm{mg} \mathrm{kg}^{-1}\right.$ of soil) & 100 & 300 & 150 \\
Fertilizer source & Urea & $\mathrm{MAP}$ & $\mathrm{K}_{2} \mathrm{SO}_{4}$ \\
Fertilization $(\mathrm{g}$ per lysimeter) & 21.5 & 121.1 & 72.2 \\
Monthly amount $\left(\mathrm{g}\right.$ month $\left.^{-1}\right)$ & 1.8 & 10.1 & 6.1 \\
\hline
\end{tabular}

The water of different levels of electrical conductivity $(\mathrm{ECW})$ were prepared by dissolving commercial $\mathrm{NaCl}$ (without iodate) into the water and confirming levels using a benchtop conductivity meter (Model Digimed DM-32). Irrigation frequency was based on plant water demand, with a typical interval of two or three days. Water consumption by plants was calculated using the water balance (applied volume minus the volume drained in the previous irrigation) and adding a leaching fraction (LF) of 0.10 .

\section{Analyzed variables and statistical analysis}

At the end of the study period, the following physiological variables were determined in both experiments: internal $\mathrm{CO}_{2}$ concentration (Ci), transpiration $(E)$, stomatal conductance $(g s)$, and $\mathrm{CO}_{2}$ assimilation rate $(A)$. These variables were calculated using the third leaf from the apex and a portable device for photosynthesis measurements ("LCPro+"; ADC BioScientific Ltda.). After obtaining these data, water use efficiency (WUE) ( $A$ / E) and the instantaneous carboxylation efficiency $\operatorname{EffCi}(A / \mathrm{Ci})$ were quantified (KONRAD et al., 2005; MACHADO, 2010, BRITO et al., 2012).
In February 2014, mature fruit were harvested, counted, weighed (precision scale; 0.001 $\mathrm{g}$ resolution). Total mass and number of fruits were used to calculate the mean mass of fruits.

Using the statistical program SISVAR (FERREIRA, 2011), the results were subjected to analysis of variance using an F-test, means for the rootstocks were compared using a Tukey's test, and a polynomial regression was used to analyze the levels of irrigation water salinity.

\section{RESULTS AND DISCUSSION}

\section{Experiment I: Salinity tolerance of scion- rootstock combinations}

Based on the analysis, there was no significant effect $(p>0.05)$ of water salinity $\times$ rootstocks interaction for any of the physiological variables. However, there was a significant $(p<$ 0.01 ) interaction for the mean mass of fruits (Table 4). Internal $\mathrm{CO}_{2}$ concentration was consistent across all treatments. Regardless of the rootstock, transpiration $(E)$, stomatal conductance $(\mathrm{gs}), \mathrm{CO}_{2}$ assimilation rate $(A)$, and instantaneous 
carboxylation efficiency (EffCi) responded to the isolated effects $(\mathrm{p}<0.01)$ of irrigation water salinity. As for water use efficiency, the rootstocks showed similar responses to the salinity levels, but, according to the $\mathrm{F}$ test, responded differently $(\mathrm{p}<$ $0.05)$. The osmotic stress caused by saline water irrigation significantly reduced water use efficiency and gas exchanges, but the magnitude of the reduction depended on the duration of the saline stress and on the sensitivity of the rootstock to the toxic ions. Silva et al. (2014) observed similar effects of water salinity on gas exchanges of citrus plants and identified tolerant rootstocks after only 48 hours of exposure to the stress, thus denoting the severity of the increase in soil salinity.

Table 4. Summary of the analysis of variance for internal $\mathrm{CO}_{2}$ concentration $(\mathrm{Ci})$, transpiration $(E)$, stomatal conductance (gs), $\mathrm{CO}_{2}$ assimilation rate $(A)$, water use efficiency (WUE), instantaneous carboxylation efficiency (EffCi), and mean mass of fruit (MMF), under different of water salinity (Sal) and citrus rootstocks (RS) grafted with Mimo do Céu orange (Citrus sinensis OSBECK var. Mimo), at 210 days after the beginning of flowering.

\begin{tabular}{|c|c|c|c|c|c|c|c|c|}
\hline \multirow{2}{*}{ Source of variation } & \multirow{2}{*}{$\mathrm{DF}$} & \multicolumn{7}{|c|}{ Mean Square } \\
\hline & & $\mathrm{Ci}$ & $E^{1}$ & $\mathrm{gs}^{1}$ & $A$ & WUE $^{1}$ & $\mathrm{EffCi}^{1}$ & MMF \\
\hline Salinity (Sal) & 4 & $2346.5^{\mathrm{ns}}$ & $4.4^{* *}$ & $0.03^{* *}$ & $71.3^{* *}$ & $0.34^{\mathrm{ns}}$ & $0.0015^{* *}$ & $68445.86^{* *}$ \\
\hline Linear Reg. & & $0.7^{\mathrm{ns}}$ & $17.3^{* *}$ & $0.11^{* *}$ & $275.5^{* *}$ & $0.07^{\mathrm{ns}}$ & $0.005^{* *}$ & $272763.08^{* *}$ \\
\hline Quadratic Reg. & & $8017.1^{\mathrm{ns}}$ & $0.0^{\mathrm{ns}}$ & $0.01^{\mathrm{ns}}$ & $2.9^{\mathrm{ns}}$ & $0.6^{\mathrm{ns}}$ & $0.0005^{\mathrm{ns}}$ & $458.18^{* *}$ \\
\hline Rootstock (RS) & 2 & $3705.8^{\mathrm{ns}}$ & $0.3^{\mathrm{ns}}$ & $0.01^{\mathrm{ns}}$ & $4.9^{\mathrm{ns}}$ & $3.16^{*}$ & $0.00034^{\mathrm{ns}}$ & $3588.29^{* *}$ \\
\hline Sal x RS & 8 & $1018.2^{\mathrm{ns}}$ & $0.3^{\mathrm{ns}}$ & $0.01^{\mathrm{ns}}$ & $1.5^{\mathrm{ns}}$ & $1.14^{\mathrm{ns}}$ & $0.000097^{\mathrm{ns}}$ & $214.79^{* *}$ \\
\hline Block & 2 & 15.6 & 0.1 & 0.001 & 5.19 & 1.13 & 0.00012 & 472.62 \\
\hline Residue & 28 & 38955.4 & 0.3 & 0.021 & 5.16 & 0.82 & 0.00021 & 21.86 \\
\hline $\mathrm{CV}$ & & 15.4 & 12.1 & 19.85 & 11.85 & 11.27 & 16.48 & 2.67 \\
\hline Overall mean & & 232.9 & 1.8 & 0.1 & 7.1 & 4.2 & 0.03 & 175.3 \\
\hline
\end{tabular}

**significant at $\mathrm{p}<0.01$; *significant at $\mathrm{p}<0.05$; ns: not significant. ${ }^{1}$ Statistical analysis performed after transforming the data to $\sqrt{X}$.

As indicated in Figure 1, there was a negative relationship between irrigation water salinity and transpiration (E), stomatal conductance (gs), $\mathrm{CO}_{2}$
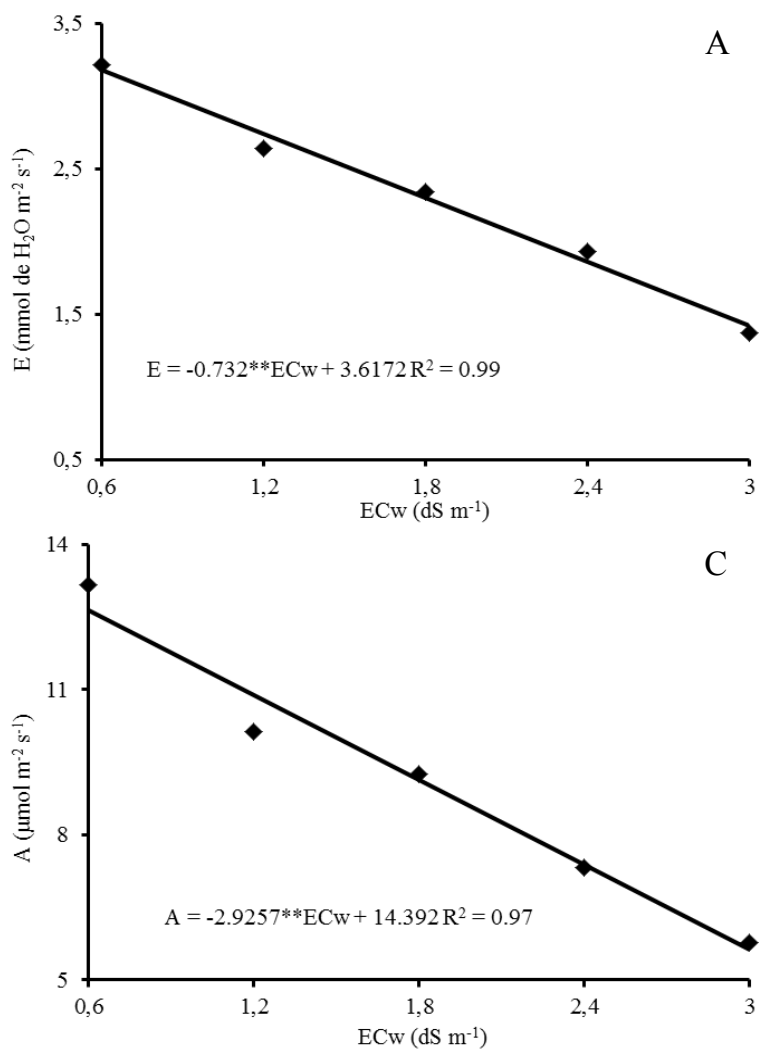

assimilation rate (A), and instantaneous carboxylation efficiency (EffCi).
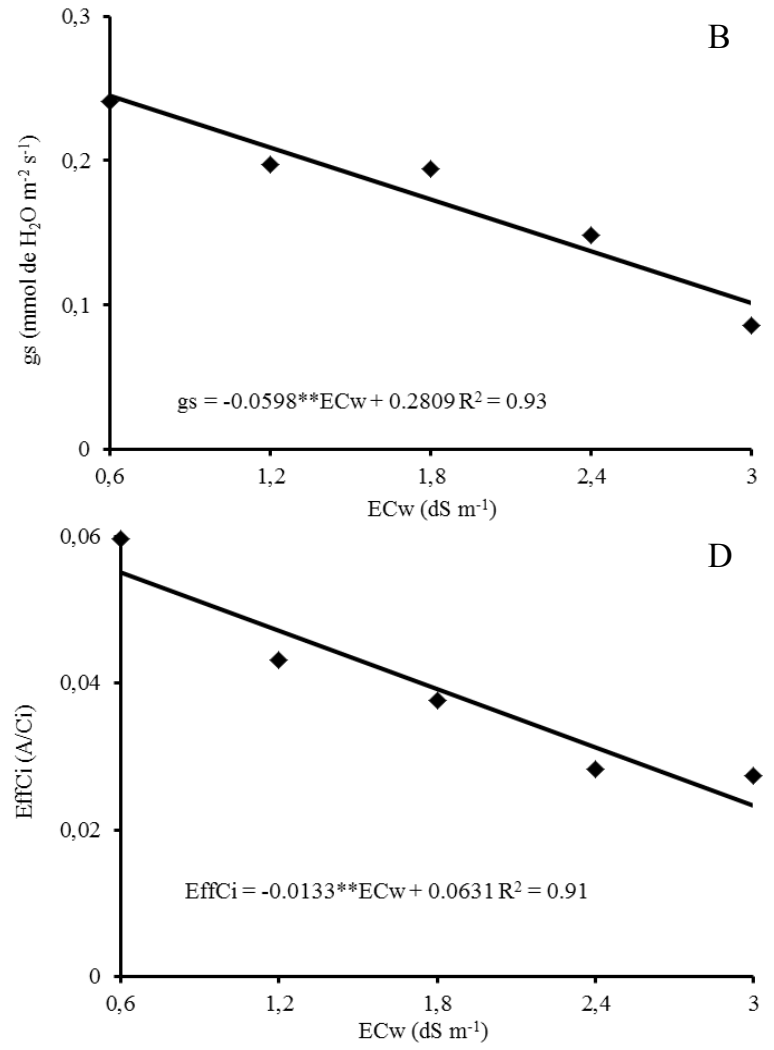

Figure 1. Transpiration - $E(\mathrm{~A})$, stomatal conductance - $g s(\mathrm{~B}), \mathrm{CO}_{2}$ assimilation rate - $A(\mathrm{C})$, and instantaneous carboxylation efficiency - EffCi (D), as a function of irrigation water salinity, in citrus grafted with Mimo do Céu orange (Citrus sinensis OSBECK var. Mimo), at 210 days after the beginning of flowering. 
The transpiration rate (Figure 1A) decreased from 3.178 to $1.421 \mathrm{mmol} \mathrm{H}_{2} \mathrm{O} \mathrm{m} \mathrm{m}^{-2} \mathrm{~s}^{-1}$, from the lowest salinity treatment $\left.(0.6 \mathrm{dS} \mathrm{m})^{-1}\right)$ to the highest $\left(3.0 \mathrm{dS} \mathrm{m}^{-1}\right)$, respectively. This equates to an overall reduction of $55.28 \%$ and a $20.24 \%$ reduction in transpiration rate per unit increase in water salinity. Taiz and Zeiger (2013) defined transpiration as the process in which energy, in the form of latent heat, is transferred from the leaf to the air. The reduction in transpiration observed in the present study must have been due to stomatal closure in response to osmotic stress caused by the increase in salinity. This process is known as the mechanism of acclimation to saline stress.

In the present study, the closure of the stomata was due to the osmotic conditioning imposed by the increasing levels of irrigation water salinity. This can be directly linked to the stomatal conductance, which decreased in a similar way. According to the regression analysis, there were stomatal conductance reductions of 14.64, 29.29, 43.93, and $58.57 \%$, when compared water salinity treatments of $1.2,1.8,2.4$, and $3.0 \mathrm{dS} \mathrm{m}^{-1}$ with 0.6 $\mathrm{dS} \mathrm{m}{ }^{-1}$, respectively, which correspond to a reduction per unit increase water salinity of $21.29 \%$. (Figure 1B). According to Gonçalves et al. (2010), there is a direct relationship between $E$ and gs, with water vapor flow to the atmosphere decreasing as the stomata close. Therefore, there is a reduction in transpiration and, consequently, a reduction in stomatal conductance. This trend was observed in this current study, with a reduction of $55.28 \%$ in transpiration and $58.57 \%$ in stomatal conductance between the lowest and the highest levels of salinity.

Due to the reduction in transpiration rate and stomatal conductance, photosynthesis $(A)$ (Figure 1C) was negatively impacted and there was a reduction of approximately $20.33 \%$ per unit increase in $\mathrm{ECw}$. This is explained by López-Climent et al. (2008), who revealed that plants, when subjected to saline stress, tend to show reduction in net $\mathrm{CO}_{2}$ assimilation rate, due to the stomatal effects. This is because the closing of the stomata restricts the entry of $\mathrm{CO}_{2}$ into the cells, and therefore is the main cause of the reduction of photosynthesis (MUSYIMI; NETONDO; OUMA, 2007). In addition, such restriction can increase the susceptibility of the plant to photochemical damages, because low $\mathrm{CO}_{2}$ assimilation rates cause excess levels of light energy in photosystem II; this has been observed in studies on fluorescence (SILVA et al., 2010; SILVA et al., 2014).

According to Konrad et al. (2005), non-stomatal factors may compromise photosynthesis, and this can be studied using the instantaneous carboxylation efficiency (EffCi). In the present study, EffCi was reduced by 14.48 , $28.96,43.43$, and $57.91 \%$ in the comparison between water salinity of $0.6 \mathrm{dS} \mathrm{m}^{-1}$ and treatments of 1.2 , $1.8,2.4$ and $3.0 \mathrm{dS} \mathrm{m}^{-1}$, respectively (Figure 1D).
According to Larcher (2006), this reduced efficiency is related to the metabolic restrictions in the Calvin cycle, where the received carbon is not being fixed in the carboxylation stage in the mesophyll cells. According to Taiz and Zeiger (2013), as the stress becomes rigorous, the dehydration of mesophyll cells inhibits photosynthesis, the mesophyll metabolism is damaged, and, consequently, the carboxylation efficiency is compromised. Furthermore, Tezara et al. (2005) attribute this reduction to the effects of water stress, resulting from the reduction in EffCi, relating it to the loss of activity of the RuBP enzyme, which may also have occurred with the saline stress caused by the waters of higher electrical conductivity.

Lloyd and Howie (1989) found a correlation between gas exchanges and salinity in citrus orchards in Australia, and attributed the deleterious effects to the accumulation of $\mathrm{Na}^{+}$and $\mathrm{Cl}^{-}$ions, especially when there were low concentrations of $\mathrm{Ca}$ and $\mathrm{K}$ in the leaves. However, despite the leaf damage caused by $\mathrm{Na}^{+}$and $\mathrm{Cl}^{-}$, the worsening of salinity effects is also dependent on the relative sensitivity of the genotype of the rootstock. High sensitivity compromises gas exchanges, through specific ion toxicity (e.g., citrus leaves with high $\mathrm{Cl}^{-}$ concentrations; STOREY; WALKER, 1999) and osmotic stress (e.g., stomatal conductance, transpiration, and photosynthesis in Valência orange under water deficiency; MEDINA, MACHADO; GOMES, 1999). As for water use efficiency (WUE) (Table 4), it was not significantly $(p>0.05)$ affected by water salinity; however, significant differences ( $p$ $<0.05$ ) were observed among the rootstocks. Among the studied rootstocks, RS1 $\left(4.505 \mu \mathrm{mol} \mathrm{m} \mathrm{m}^{-2}\right.$

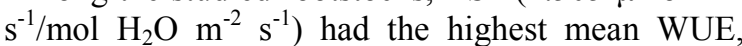
which were significantly higher $(19.8 \%)$ than the mean WUE for RS3 $\left(3.613 \mu \mathrm{mol} \mathrm{m}^{-2} \mathrm{~s}^{-1} / \mathrm{mol} \mathrm{H}_{2} \mathrm{O} \mathrm{m}\right.$ $2 \mathrm{~s}^{-1}$ ) (Figure 2). This lower WUE for RS3 may have been due to the reduction in plant growth resulting from the saline stress, which led to a reduction in water use efficiency.

With regard to mean mass of fruit (MMF), for all levels of water salinity, RS1 and RS2 had a greater MMF compared to RS3 (Figure 3A). RS2 had a significantly greater MMF than RS1, but only at the salinity levels of 0.6 and $2.4 \mathrm{dS} \mathrm{m}^{-1}$. There was a negative linear relationship between MMF and salinity levels (Figure 3B), and RS2 had the overall highest means. In RS1, RS2, and RS3 MMF were reduced by $26.69 \%, 26.51 \%$, and $27.69 \%$, respectively, with per unit increase in ECw. Based on the MMF values, RS1 and RS2 were more tolerant to saline conditions than RS3.

According to Taiz and Zeiger (2013), plants under saline stress can show osmotic adjustment, as a mechanism of tolerance, allowing for a reduction in water potential and absorption of water and nutrients. However, the lack of water reduces turgor pressure, thereby reducing the sap flow through the 


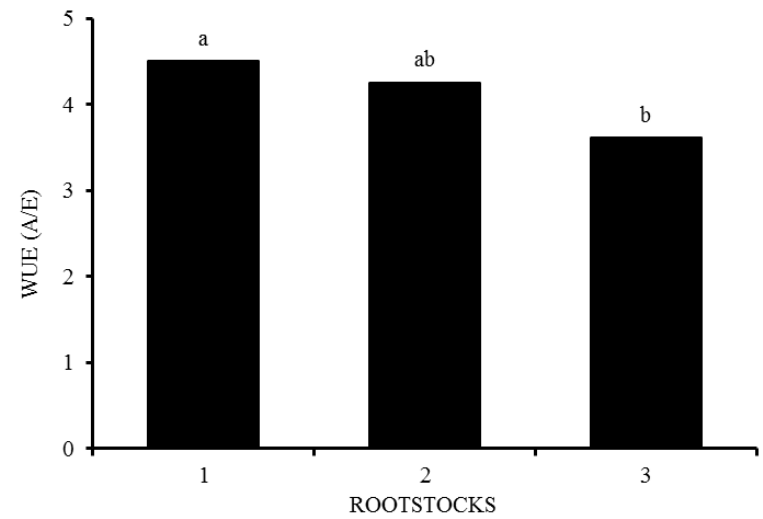

RS1 - TSKC (Tangerineira 'Sunki Comum' (Citrus sunki (Hayata) hort. ex Tanaka)) x TRENG (Poncirus trifoliata 'English') - 256 RS2 - LCRC (Limoeiro Cravo 'Comum') RS3 - TSKC (Tangerineira 'Sunki Comum' (Citrus sunki (Hayata) hort. ex Tanaka)) x (LCR x TR) (Limão Cravo x Poncirustrifoliata) -059.

Figure 2. Water use efficiency (WUE), as a function of irrigation water salinity, in citrus grafted with scion of Mimo do Céu orange (Citrus sinensis OSBECK var. Mimo), at 210 days after the beginning of flowering.
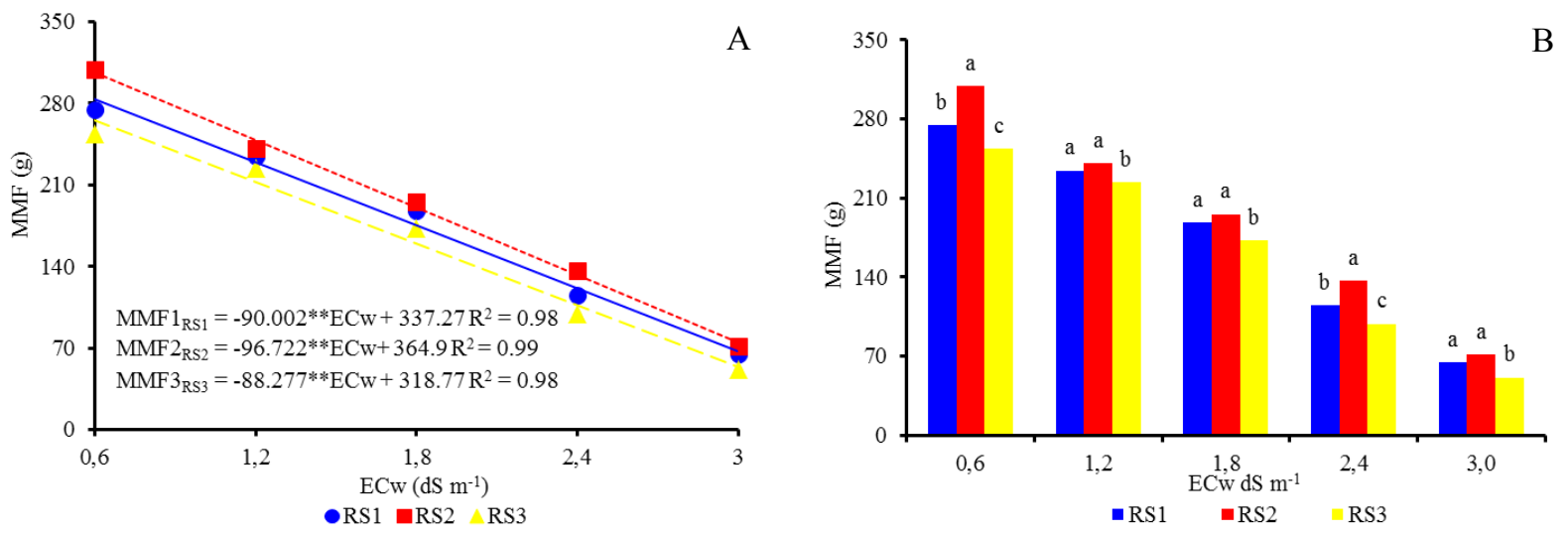

RS1 - TSKC (Tangerineira 'Sunki Comum' (Citrus sunki (Hayata) hort. ex Tanaka)) x TRENG (Poncirus trifoliata 'English') - 256 RS2 - LCRC (Limoeiro Cravo 'Comum') RS3 - TSKC (Tangerineira 'Sunki Comum' (Citrus sunki (Hayata) hort. ex Tanaka)) x (LCR x TR) (Limão Cravo x Poncirustrifoliata) -059.

Figure 3. Mean mass of fruits (MMF) for citrus genotypes used as rootstocks at each water salinity level (A) and regression between the mean mass of fruits (B) as a function of irrigation water salinity, in citrus grafted with scion of Mimo do Céu orange (Citrus sinensis OSBECK var. Mimo), at 210 days after the beginning of flowering.

conducting vessels, causing retardation in cell elongation and plant production. According to Almeida et al. (2011), the ability of plants to minimize the negative effects of salinity varies among genotypes, as also evidenced by Brito et al. (2014) and Silva et al. (2014), who studied citrus rootstock genotypes under saline conditions and confirmed the deleterious action of salinity on the citrus scion/rootstock combinations.

\section{Experiment II - Nitrogen fertilization as attenuator of saline stress}

According to the data in Table 5, there were no significant $(\mathrm{p}>0.05)$ scion/rootstock combinations $\times \mathrm{N}$ dose interactions for any of the physiological variables; however, $\mathrm{N}$ dose did have a significant effect $(\mathrm{p}<0.05)$ on transpiration $(E)$, stomatal conductance (gs), and $\mathrm{CO}_{2}$ assimilation rate $(A)$, and the mean mass of fruits varied significantly $(\mathrm{p}<0.05)$ among the rootstocks. The lack of significant effects may have been because of the loss of $\mathrm{N}$ through volatilization. High temperatures (above $30{ }^{\circ} \mathrm{C}$ ) favor the volatilization of $\mathrm{NH}_{3}$, possibly due to the higher efficiency of the ureases in the hydrolysis of urea under high temperatures (KRAJEWSKA, 2009; TASCA et al., 2011). Our results support the idea of $\mathrm{N}$ losses through volatilization, resulting in reductions in its use by plants. 
Table 5. Summary of the analysis of variance for internal $\mathrm{CO}_{2}$ concentration $(\mathrm{Ci})$, transpiration $(E)$, stomatal conductance (gs), $\mathrm{CO}_{2}$ assimilation rate $(A)$, water use efficiency (WUE), instantaneous carboxylation efficiency (EffCi), and mean mass of fruits (MMF) as a function of different doses of nitrogen (N) and citrus rootstocks (RS) grafted with Mimo do Céu orange (Citrus sinensis OSBECK var. Mimo), at 210 days after the beginning of flowering.

\begin{tabular}{lcccccccc}
\hline \multirow{2}{*}{$\begin{array}{l}\text { Source of } \\
\text { variation }\end{array}$} & \multirow{2}{*}{ DF } & \multicolumn{7}{c}{ Mean Square } \\
\cline { 3 - 8 } & & $\mathrm{Ci}^{1}$ & $E^{1}$ & $\mathrm{gs}^{1}$ & $A^{1}$ & WUE $^{1}$ & EffCi $^{1}$ & MMF \\
\hline Nitrogen (N) & 1 & $183618^{\text {ns }}$ & $3.025^{*}$ & $0.022^{*}$ & $33.633^{*}$ & $0.673^{\text {ns }}$ & $0.000356^{\text {ns }}$ & $8.005^{\text {ns }}$ \\
Rootstock (RS) & 2 & $1837.722^{\text {ns }}$ & $0.022^{\text {ns }}$ & $0.0014^{\text {ns }}$ & $4.987^{\text {ns }}$ & $1.004^{\text {ns }}$ & $0.000233^{\text {ns }}$ & $626.127^{* *}$ \\
N x RS & 2 & $3157.167^{\text {ns }}$ & $0.18^{\text {ns }}$ & $0.0027^{\text {ns }}$ & $3.142^{\text {ns }}$ & $3.332^{\text {ns }}$ & $0.00016^{\text {ns }}$ & $1.38^{\text {ns }}$ \\
Block & 2 & 4355.722 & 0.341 & 0.0034 & 4.619 & 1.164 & 0.000324 & 56.289 \\
Residue & 10 & 1909.922 & 0.34 & 0.0033 & 4.46 & 0.941 & 0.000087 & 5.423 \\
CV & & 10.46 & 16.83 & 25.2 & 14.62 & 11.18 & 13.9 & 3.69 \\
\hline Mean & & 232.944 & 1.783 & 0.12 & 7.144 & 4.214 & 0.0318 & 63.075 \\
\hline
\end{tabular}

**significant at $\mathrm{p}<0.01$; *significant at $\mathrm{p}<0.05$; ns: not significant. ${ }^{1}$ Statistical analysis performed after transforming the data to $\sqrt{X}$. .

Based on the variables $E$, gs, and $A$ (Figure 4), plants subjected to the treatment of $200 \%$ of $\mathrm{N}$ recommendation (N2) show better physiological conditions compared with plants irrigated with water of $3.0 \mathrm{dS} \mathrm{m}^{-1}$ without the increment in $\mathrm{N}$ fertilization (N1). There is an equivalence with the level of 1.8 $\mathrm{dS} \mathrm{m}^{-1}$ from Experiment I, which is interesting, especially when the farmer has only water with high salt content. Transpiration increased by $37.39 \%$ from $\mathrm{N} 1$ to $\mathrm{N} 2$, which is more evident when this result is compared with the treatment of $1.8 \mathrm{dS} \mathrm{m}^{-1}$ from Experiment I, where $E$ was found to be only $6.57 \%$ higher (Figure 4A). Similar results were obtained for stomatal conductance and $\mathrm{CO}_{2}$ assimilation rate, with increases of 44.87 and $32.12 \%$ between the doses of 100 and $200 \%$ of $\mathrm{N}$ fertilization, respectively (Figure 4B and 4C). In comparison with the treatment of $1.8 \mathrm{dS} \mathrm{m}^{-1}$ from Experiment I, there is a reduction of $0.038 \mathrm{mmol}$ of $\mathrm{H}_{2} \mathrm{O} \mathrm{m}^{-2} \mathrm{~s}^{-1}$ in $g s$ and $0.739 \mu \mathrm{mol} \mathrm{m} \mathrm{m}^{-2} \mathrm{~s}^{-1}$ in $A$ in relation to $\mathrm{N} 2$, indicating attenuation of the deleterious effects of salinity due to the higher $\mathrm{N}$ application.

Similar to our findings, Fernandes et al. (2010), working with melon, and Sousa et al. (2013), working with jatropha seedlings, concluded that the greater $\mathrm{N}$ supply was effective in decreasing the damages to $E, g s$, and $A$ caused by high salinity. In citrus plants, Syvertsen, Smith e Boman (1993) observed that $\mathrm{N}$ concentration decreased as $\mathrm{Cl}^{-}$concentrations increased in the leaves; however, Lea-Cox and Syvertsen (1993) reported that foliar N application increased photosynthesis rate in citrus plants subjected to saline stress. Greater stomatal resistance was observed in plants cultivated under low $\mathrm{N}$ conditions, and the authors concluded that the decrease in photosynthesis was caused by the inhibition of the activity of the RuBP enzyme (Ribulose-1,5bisphosphate carboxylase/oxygenase) (FREDEEN; GAMON; FIED, 1991).

Based on the results, despite the absence of significant effects $(\mathrm{p}>0.05)$ of $\mathrm{N}$, it is possible to note that the increase in $\mathrm{N}$ supply favored the gas exchanges of the plants, which was reflected in the MMF. For MMF, N2 treatments were superior by $0.68 \%$ (RS1), $1.65 \%$ (RS2), and $4.41 \%$ (RS3) compared with plants that received the lowest $\mathrm{N}$ dose (N1). These results suggest that a portion of the applied $\mathrm{N}$ was volatized, leading to lower $\mathrm{N}$ use by plants, which is most evident for RS3, and reflects a greater sensitivity of RS3 to saline stress than other genotypes (Figure 5).

Adequately nourished plants tend to better tolerate the effects of salinity than plants subjected to nutrient deficiencies (SANTOS et al., 2010). Saline stress inhibits $\mathrm{N}$ acquisition and use, compromising absorption, distribution, and assimilation, as well as the synthesis of proteins (ARAGÃO et al., 2010). It has been shown in sorghum and watermelon that $\mathrm{N}$ is capable of reducing the deleterious effects of salinity (FEIJÃO et al., 2011; FURTADO et al., 2012). However, it is important to note that these authors worked with nutrient solutions, providing $\mathrm{N}$ directly in the nitrate form. 

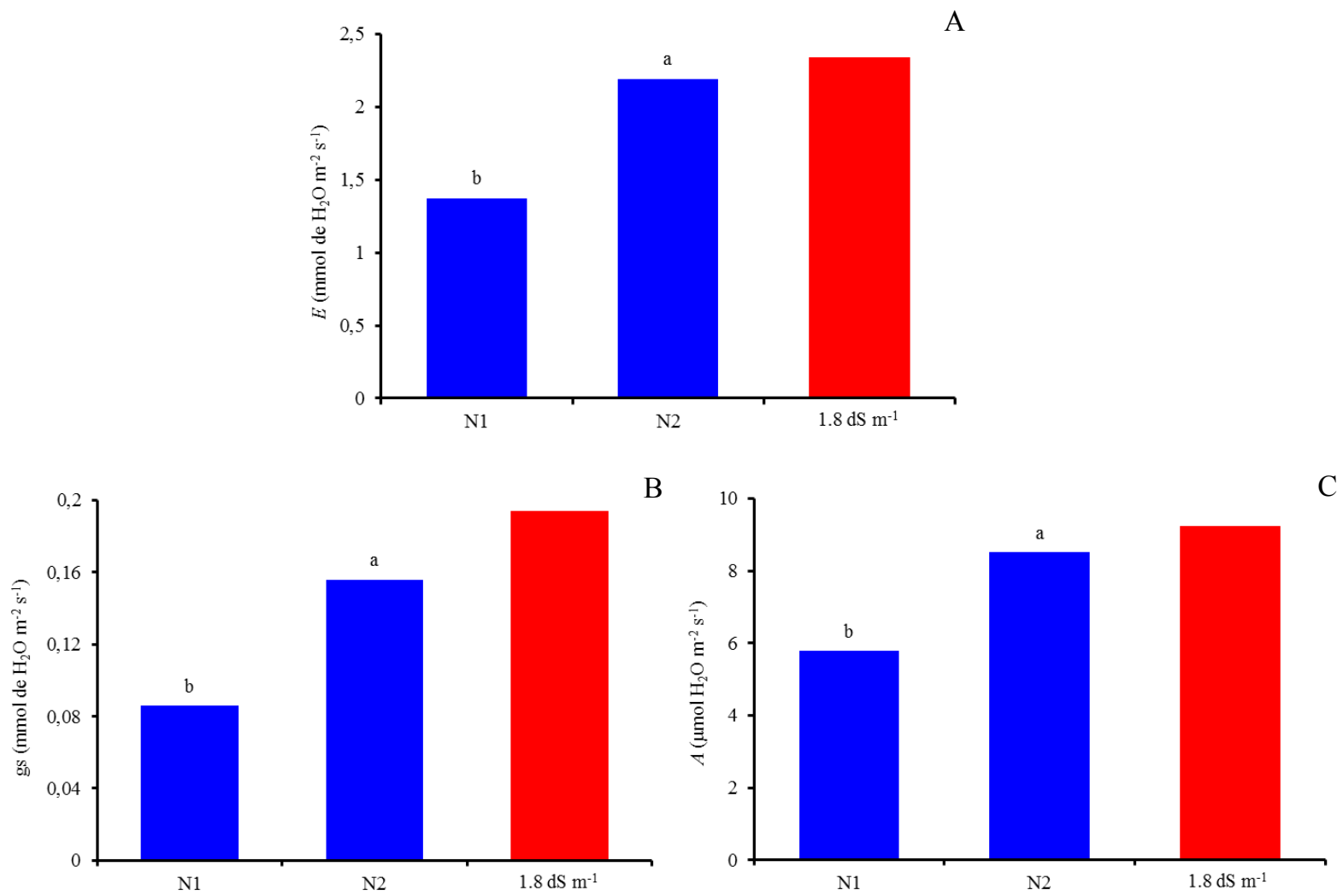

Figure 4. Transpiration- $E(\mathrm{~A})$, stomatal conductance - $g s(\mathrm{~B})$, and $\mathrm{CO}_{2}$ assimilation rate- $A(\mathrm{C})$, as a function of nitrogen doses (N1 - 100\% and N2 200\% of recommendation), in citrus grafted with scion of Mimo do Céu orange (Citrus sinensis OSBECK var. Mimo), irrigated with water of $3.0 \mathrm{dS} \mathrm{m}^{-1}$, at 210 days after the beginning of flowering, in comparison to the salinity level of $1.8 \mathrm{dS} \mathrm{m}^{-1}$ from Experiment I.

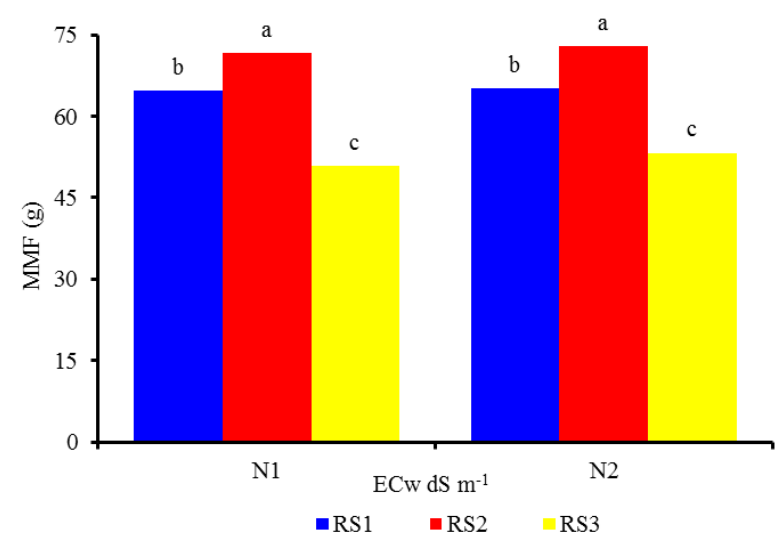

Figure 5. Mean mass of fruits (MMF) as a function of nitrogen doses (N1 - 100\% and N2 200\% of recommendation), in citrus grafted with scion of Mimo do Céu orange (Citrus sinensis OSBECK var. Mimo), irrigated with water salinity of $3.0 \mathrm{dS} \mathrm{m}^{-1}$, at 210 days after the beginning of flowering.

\section{CONCLUSIONS}

Saline stress compromises gas exchanges in citrus plants;

The increase in the salinity level of irrigation water inhibits the mean mass of fruits for the scionrootstock combinations;

Among the rootstocks, $\mathrm{TSKC} \times(\mathrm{LCR} \times \mathrm{TR}-$
059) proved to be more sensitive to water salinity;

Plants grafted with the Common Rangpur lime show greater productivity potential, even under saline water irrigation, compared with the genotypes TSKC $\times$ TRENG -256 and TSKC $\times$ LCR $\times$ TR 059 ;

The increase in nitrogen doses stimulated gas exchanges, which was reflected in the greater mean mass of fruits. 


\section{ACKNOWLEDGMENTS}

We acknowledge the National Council for Scientific and Technological Development (CNPq) for funding the project and granting the scholarship to first author.

And to Embrapa Cassava and Fruits, for send seeds from Breeding Program for Citrus Fruits.

\section{REFERENCES}

ALMEIDA, W. S. de et al. Identificação de genótipos de feijão-caupi tolerantes a salinidade avaliado por meio de método multivariado. Ciência Rural, Santa Maria. v. 41, n. 11, p. 1884-1889, 2011.

ARAGÃO, R. M. et al. Absorção, fluxo no xilema e assimilação do nitrato em feijão-caupi submetido à salinidade. Revista Ciência Agronômica, Fortaleza, v. 14, n. 1, p. 100-106, 2010.

BRITO, M. E. B. et al. Comportamento físiológico de combinações copa/porta-enxerto de citros sob estresse hídrico. Revista Brasileira de Ciências Agrarias, Recife, v. 7, suplemento, p. 857-865, 2012.

BRITO, M. E. B. et al. Growth of ungrafted and grafted citrus rootstocks under saline water irrigation. African Journal of Agricultural Research, Lagos, v. 9, n. 50, p. 3600-3609, 2014a.

BRITO, M. E. B. et al. Sensibilidade à salinidade de híbridos trifoliados e outros porta-enxertos de citros. Revista Caatinga, Mossoró, v. 27, n. 1, p. 17 - 27, 2014b.

FAO. Citrus fruit fresh and processed. Annual statistics 2013. Rome: Food and Agriculture Organization of the United Nations, 2013. 35 p.

FEIJÃO, A. R. et al. Efeito da nutrição de nitrato na tolerância de plantas de sorgo sudão à salinidade. Revista Ciência Agronômica, Fortaleza, v. 42, n. 3, p. $675-683,2011$.

FERNANDES, O. B. et al. Efeito do nitrato de cálcio na redução do estresse salino no meloeiro. Revista Caatinga, Mossoró, v. 23, n. 3, p. 93-103, 2010.

FERNANDES, P. D. et al. Crescimento de híbridos e variedades porta-enxerto de citros sob salinidade. Acta Scientiarum Agronomy, Maringá, v. 33, n. 2, p. $259-267,2011$.

FERREIRA, D. F. Sisvar: a computer statistical analysis system. Ciência e Agrotecnologia, Lavras, v. 35, n. 6, p. 1039-1042, 2011.

FREDEEN, A. L.; GAMON, J. A.; FIED, C. B. Responses of photosynthesis and carbohydrate partitioning to limitations in nitrogen and water availability in field-grown sunflower. Plant, Cell and Environment, Oxford, v. 14, n. 9, p. 963-970, 1991.

FURTADO, G. F.; Efeito do nitrato de cálcio na redução do estresse salino em melancieira. Revista Verde de Agroecologia e Desenvolvimento Sustentável, Mossoró, v. 7, n. 3, p. 33-40, 2012.

GONÇALVES, E. R. et al. Trocas gasosas e fluorescência da clorofila a em variedades de canade-açúcar submetidas à deficiência hídrica. Revista Brasileira de Engenharia Agrícola e Ambiental, Campina Grande, v. 14, n. 4, p. 378-386, 2010.

IBGE. Sidra. Citros. Disponível em: <http:// www.sidra.ibge.gov.br>. Acesso em: $10 \mathrm{dez} 2013$.

KONRAD, M. L. F. et al. Trocas gasosas e fluorescência da clorofila em seis cultivares de cafeeiro sob estresse de alumínio. Bragantia, Campinas, v. 64, n. 3, p. 339-347, 2005.

KRAJEWSKA, B. Ureases I. Functional, catalytic and kinetic properties: A review. Journal of Molecular Catalysis B: Enzymatic, Amsterdam, v. 59, n. 1-3, p. 9-21, 2009.

LARCHER, W. Ecofisiologia vegetal. São Carlos, SP: RiMa Artes e Textos, 2006. 532 p.

LEA-COX, J. D.; SYVERTSEN J. P. Salinity reduces water use and nitrate-N use efficiency of citrus. Annals of Botany, London, v. 72, n. 1, p. 47 54. 1993.

LIMA, G. S. et al. Respostas morfofisiológicas da mamoneira, em função da salinidade da água de irrigação e adubação nitrogenada. Irriga, Botucatu, v. 19, n. 1, p. 130-136, 2014.

LlOYD, J.; HOWIE, H. Salinity, stomatal responses, and whole-tree hydraulic conductivity of orchard Washington navel orange Citrus sinensis (L) Osbeck. Australian Journal of Plant Physiology, Melbourne, v. 16, n. 2, p. 169-179, 1989.

LÓPEZ-CLIMENT, M. F. et al. Relationship between salt tolerance and photosynthetic machinery performance in citrus. Environmental and Experimental Botany, Amsterdam, v. 62, n. 2, p. 176-184, 2008

MACHADO, D. F. S. P. et al. Efeito da baixa temperatura noturna e do porta-enxerto na variação 
diurna das trocas gasosas e da atividade fotoquímica de laranjeira 'Valência'. Revista Brasileira de Fruticultura, Jaboticabal, v. 32, n. 2, p. 351-359, 2010.

MARCHESAN, E. et al. Fontes alternativas à ureia no fornecimento de nitrogênio para o arroz irrigado. Ciência Rural, Santa Maria, v. 41, n. 12, p. 2053 2059, 2011.

MEDINA, C. L.; MACHADO, E. C.; GOMES, M. M. A. Condutância estomática, transpiração e fotossíntese em laranjeira 'Valência' sob deficiência hídrica. Revista Brasileira de Fisiologia Vegetal, Brasília, v. 11, n. 1, p. 29-34, 1999.

MUSYIMI, D. M.; NETONDO, G. W.; OUMA, G. Effects of salinity on gas exchange and nutrient uptake in avocados. Journal of Biological Sciences, Toronto, v. 7, n. 3, p. 496-505, 2007.

NEVES, A. L. R. et al. Acumulação de biomassa e extração de nutrientes por plantas de feijão-de-corda irrigadas com água salina em diferentes estádios de desenvolvimento. Ciência Rural, Santa Maria, v. 39, n. 3 , p. $758-765,2009$.

NOBRE, R. G. et al. Produção de girassol sob estresse salino e adubação nitrogenada. Revista Brasileira de Ciência do Solo, Campinas, v. 35, n. 3, p. 929-937, 2011.

NOBRE, R. G. et al. Sources and doses of nitrogen in the production of sunflower plants irrigated with saline water. Revista Brasileira de Engenharia Agrícola e Ambiental, Campina Grande, v. 18, suplemento, p. 59-65, 2014

NOVAIS, R. F.; NEVES, J. C. L.; BARROS, N. F. Ensaio em ambiente controlado. In: OLIVEIRA, A. J. et al. (Ed.) Métodos de pesquisa em ambiente controlado. Brasília: Embrapa-SEA, 1991, p. 189273.

SANTOS, R. V.; CAVALCANTE, L F; VITAL, A. F. M. Interações salinidade-fertilidade do solo. In: GHEYI, H. R.; DIAS, N. S.; LACERDA, C. F. (Ed.) Manejo da salinidade na Agricultura: Estudo básico e aplicados. Fortaleza: INCT Sal, 2010, Cap. 14 , p. 221-252.

SILVA, E. N. et al. Comparative effects of salinity and water stress on photosynthesis, water relations and growth of Jatropha plants. Journal of Arid Environments, London, v. 74, n. 10, p. 1130-1137, 2010.

SILVA, L. A. et al. Mecanismos fisiológicos em híbridos de citros sob estresse salino em cultivo hidropônico. Revista Brasileira de Engenharia
Agrícola e Ambiental, Campina Grande, v. 18, suplemento, p. 1-7, 2014.

SOARES, L. A. dos A. et al. Fisiologia e acúmulo de fitomassa pela mamoneira submetida a estresse salino e adubação nitrogenada. Revista Verde de Agroecologia e Desenvolvimento Sustentável, Mossoró, v. 8, n. 1, p. 247-256, 2013.

SOUSA, J. R. M.; ALVINO, F. C. G.; BRITO, M. E. B. Viabilização no uso da água salina em pinhão manso. In: MESSIAS, A. S.; FRADIQUE, P. C. N. (Ed.) Gestão de água: água, meio ambiente e saúde. Recife: UNICAP, 2013. v. 1, p. 866-875.

STOREY, R.; WALKER, R. R. Citrus and salinity. Scientia Horticulturae, Amsterdam, v. 78, n. 1-4, p. 39-81, 1999.

SYVERTSEN, J. P., GARCIA-SANCHEZ, F Multiple abiotic stresses occurring with salinity stress in citrus. Environmental and Experimental Botany, Oxford, v. 103, s. n., p. 128-137, 2014.

SYVERTSEN, J. P.; SMITH, M. L.; BOMAN, B. J. Tree growth, mineral nutrition, and nutrient leaching losses from soil of salinized citrus. Agriculture, Ecosystems \& Environment, Amsterdam, v. 45, n. 3-4, p. 319-334. 1993.

TAIZ, L.; ZEIGER, E. Fisiologia vegetal. Porto Alegre, RS: ArtMed, 2013. 828 p.

TASCA, F. A. et al. Volatilização de amônia do solo após a aplicação de ureia convencional ou com inibidor de urease. Revista Brasileira de Ciência do Solo, Viçosa, v. 35, n. 2, p. 493-502, 2011.

TEZARA, W. et al. Photosynthesis and photoinhibition in two xerophytic shrubs during drought. Photosynthetica, Praha, v. 43, n. 1, p. 3745, 2005. 